DOI: $10.1515 /$ LPTS-2015-0018

MATERIALS SCIENCE

\title{
NATURAL RADIOACTIVITY IN CLAY AND BUILDING MATERIALS USED IN LATVIA
}

\author{
D. Riekstina ${ }^{1}$, J. Berzins ${ }^{1}$, T. Krasta ${ }^{1}$, R. Svinka ${ }^{2}$, O. Skrypnik ${ }^{3}$ \\ ${ }^{1}$ Institute of Solid State Physics, University of Latvia, \\ 8 Kengaraga Str., Riga, LV-1063, LATVIA \\ ${ }^{2}$ Institute of Silicate Materials Science, Riga Technical University, \\ 14/24 Azenes Str., Riga, LV-1048, LATVIA \\ ${ }^{3}$ Institute of Chemical Physics, University of Latvia, \\ 19 Raina Blvd., Riga, LV-1586, LATVIA
}

This paper presents the results of natural radionuclide concentration and activity index study in materials used for construction in Latvia. Special attention is given to clay and clay ceramics. Concentrations of K-40 and Th232 , U-238 radioactivity were determined using gamma-spectrometry method. In some building ware, maximal concentration of K-40 was $1440 \mathrm{~Bq} / \mathrm{kg}$, and of $\mathrm{U}-238-175 \mathrm{~Bq} / \mathrm{kg}$. In granite, the determined maximum concentration of Th-232 was $210 \mathrm{~Bq} / \mathrm{kg}$. It was found that radionuclide content in different period clay deposits can differ by more than two times, and up to five times in different clay ceramics. The results obtained are compared with analogous data from the other Baltic and North European countries.

Keywords: Activity index, building materials, clay, environment, natural radionuclides.

\section{INTRODUCTION}

Surveys show that modern people spend approximately $80 \%$ of their lifetime indoors [1]. Most of materials used for construction purposes are made of natural raw materials: stone, sand, lime, clay, etc., containing naturally occurring radioactive materials (NORMs) K-40, and Th-232, U-238 (Ra-226) decay chain products. Therefore, building materials can be a significant source of external and internal gamma-ray exposure for the population [2]. Knowledge of natural radioactivity level from the used building materials is important in order to adopt precautionary measures and reduce harmful effects of ionizing radiation.

The European Commission has developed recommendations [3] for classification of building materials according to their radiation safety. With regard to these 
recommendations, the European [4] and Latvian national [5] regulations have been developed stating that the maximum permissible level for activity concentration of NORMs in building materials is determined using activity index I (in $\mathrm{Bq} / \mathrm{kg}$ ):

$$
\mathrm{I}=\mathrm{C}_{\mathrm{K}} / 3000+\mathrm{C}_{\mathrm{Ra}} / 300+\mathrm{C}_{\mathrm{Th}} / 200,
$$

where: $\mathrm{C}_{\mathrm{K}}$ - the concentration of potassium- $40(\mathrm{~Bq} / \mathrm{kg})$;

$\mathrm{C}_{\mathrm{Ra}}$ - the concentration of radium-226 $(\mathrm{Bq} / \mathrm{kg})$;

$\mathrm{C}_{\mathrm{Th}}$ - the concentration of thorium-232(Bq/ $\left.\mathrm{kg}\right)$.

The maximum permissible level is set so that the annual gamma-radiation dose for the exposed population does not exceed 0.3-1.0 mSv.

Our study presents a synopsis of NORM activity measurement results for a representative range of raw and building materials used in Latvia. Samples of materials subjected to certification with regard to the above-mentioned regulations have been provided by various supplier and construction firms during the last ten years. The most attention has been given to building materials of Latvian origin: specifically, clay and clay ceramics which are widely used in construction due to local availability.

The knowledge of NORM concentration in raw and building materials is essential both to national and local authorities, as well as to construction firms in order to develop guidelines for the use of these materials reducing possible radiological hazards for the population.

As yet, Latvia is one of a few EU countries for which one cannot find published results of NORM activity measurements in building materials [6], [7]. The aim of this study is to fill that gap and to present data which could be included in European and global databases [1], [7], as well as used for comparison with analogous data from the Baltic region countries [8]-[10].

\section{EXPERIMENTAL PART}

In order to determine concentrations (specific activity) of natural radionuclides K-40, and the decay products of Th-232 and U-238 (Ra-226) chains in various materials, we have employed the gamma-ray spectrometry method LVS/ISO 257:2000 [11] developed on the basis of ISO 18589 standard [12]-[14].

Gamma-spectra of samples have been measured within the energy range of 50-2000 keV using the high purity germanium (HPGe) detectors and gammaspectrometers Ortec and Canberra with the Genie ${ }^{\mathrm{TM}} 2000$ software system [15]. A detector is placed in a well made of $8 \mathrm{~cm}$ thick layer of lead lined on the inner side with cadmium, copper, and plexiglas coating. The energy resolution of the experimental set-up was $1.9 \mathrm{keV}$ at $1332.5 \mathrm{keV}$ gamma-line of Co-60.

Gamma-spectrometers have been calibrated for gamma energy and efficiency measurements using certified mixed standard volume source (Czech Metrology Institute) traceable to NIST. The regular energy and efficiency stability checks of gamma-spectrometers have been carried out using certified Co-60, Cs-137, and K-40 sources. 
Before starting measurements all samples were homogenized, dried at $105^{\circ} \mathrm{C}$ to achieve constant weight, filled into 11 Marinelli beakers and weighted. In order to allow Ra-226 and its short-lived decay products to achieve secular equilibrium in accordance with the Bateman equation [16], the hermetically closed beakers were stored for at least four weeks.

The measurement time of each sample was 20 hours. The activity concentration of Ra-226 (U-238) was determined from the $351.9 \mathrm{keV}$ gamma-line of $\mathrm{Pb}-214$, and the $609.3 \mathrm{keV}$ gamma-line of Bi-214; the activity of Th-232 - from the 911.1 $\mathrm{keV}$ gamma-line of Ac-228, and the $583.1 \mathrm{keV}$ gamma-line of Tl-208; but the activity of K-40 - from the $1460.8 \mathrm{keV}$ gamma-line. The secular equilibrium state in the measured sample has been checked by comparing activity concentrations obtained from gamma-lines of nuclides belonging to different decay chains: $\mathrm{Pb}-214$ and $\mathrm{Bi}-$ 214 for U-238; and Tl-208 and Ac-228 for Th-232.

The uncertainty of measurement results was within the range of $2-10 \%$, the minimum detectable activity $-0.3 \mathrm{~Bq} / \mathrm{kg}$. The credibility of the obtained results was ensured by the quality assurance and control in accordance with the main requirements of ISO/IEC 17025:2008 standard [17].

\section{RESULTS AND DISCUSSION}

All tested materials were grouped according to their usage as follows: auxiliary materials (hydro-insulation, concrete additives, anti-corrosion agents, glues, and others); granite, marble; sand, gravel; cement, lime, putty, finishing materials; building ware (plumbing, expanded clay and concrete blocks; plastic boards). Clay and clay ceramics (bricks, tiles, pipes, etc.) have been considered paying more attention as a separate group. Data have been obtained from 173 samples of different building materials and products, manufactured in Latvia as well as imported.

Table 1 shows mean values of K-40, Th-232, Ra-226 radionuclide concentrations $\mathrm{C}$, and their statistical error $\Delta \mathrm{C}$ (in brackets) for the largest groups of building materials ( $\mathrm{N}$ - number of samples). In Fig.1, we present maximum concentration values found in each of the groups, while Fig. 2 shows corresponding activity index I values.

Table 1

Average Natural Radionuclide Concentration in Building Materials, Bq/kg

\begin{tabular}{lcccc}
\hline \multicolumn{1}{c}{ Material } & $\mathbf{N}$ & $\mathbf{C}_{\mathbf{K}}\left(\Delta \mathbf{C}_{\mathbf{K}}\right)$ & $\mathbf{C}_{\mathbf{T h}}\left(\Delta \mathbf{C}_{\mathbf{T h}}\right)$ & $\mathbf{C}_{\mathbf{R a}}\left(\Delta \mathbf{C}_{\mathbf{R a}}\right)$ \\
\hline Granite & 11 & $810(73)$ & $87(19)$ & $40(14)$ \\
Cement, lime & 19 & $114(28)$ & $20(6)$ & $18(3)$ \\
Sand, gravel & 9 & $425(14)$ & $14.9(14)$ & $15.4(13)$ \\
Paint & 12 & $25(17)$ & $2.3(7)$ & $5.6(21)$ \\
Building ware & 15 & $425(105)$ & $29(10)$ & $42(13)$ \\
\hline
\end{tabular}

The highest concentrations of all three radionuclides have been found in granite, and in some kinds of building ware, e.g., in concrete blocks, expanded clay 
products. In some sorts of granite, expanded clay blocks and firebricks, radioactivity concentration exceeded the limits allowed by regulations. High contents of Th-232, and U-238 have also been found in clay.

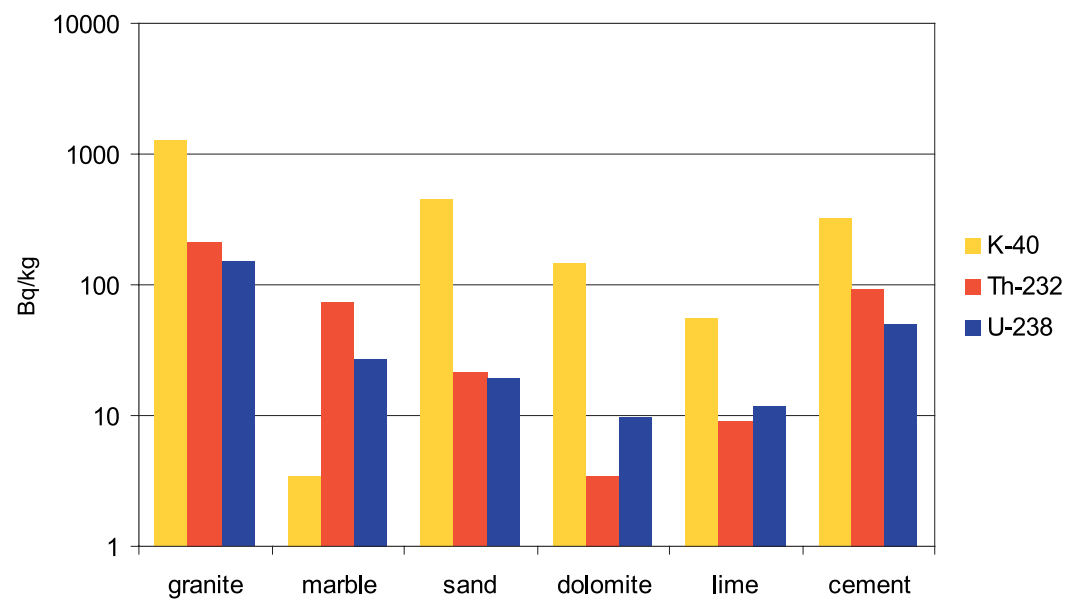

Fig. 1. Maximum concentrations of radionuclides in different building materials used in Latvia.

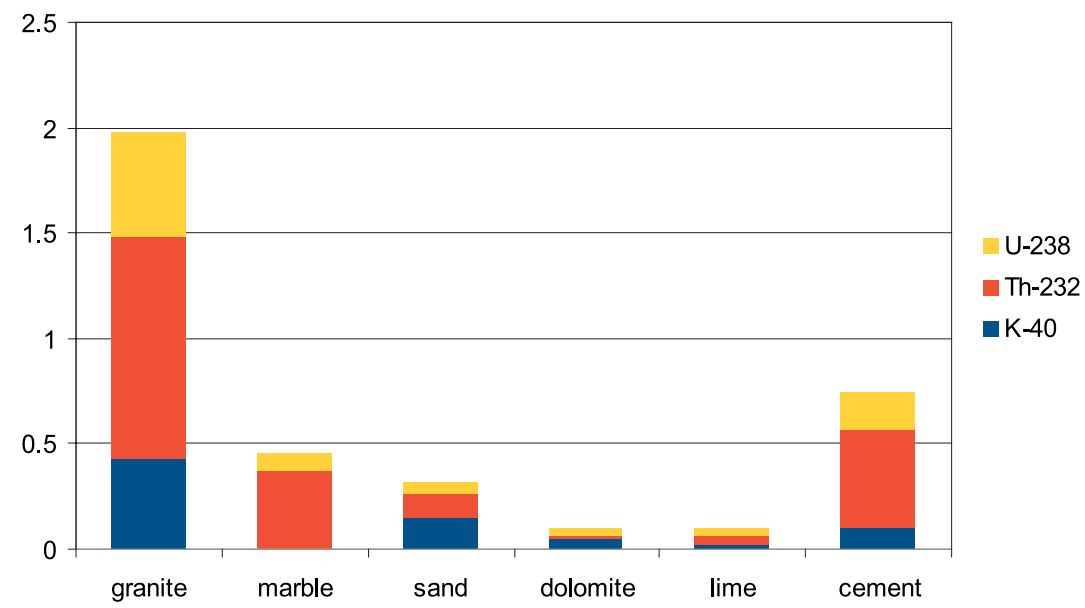

Fig.2. Maximum activity index values for tested building materials.

In Latvia, clay is obtained from two deposits (Fig. 3) belonging to Devonian and Quaternary periods [18]. With regard to the results obtained, we have undertaken a systematic study of natural radionuclide content in clay-based building materials produced by various firms in different years.

Figures 4 and 5 illustrate the results of natural radionuclide concentration measurements for clay samples taken from two Latvian deposits $(\mathrm{N}=3$ for each deposit), while Figs. 6 and 7 present data obtained from $\mathrm{N}=5$ samples of clay bricks produced in Latvia and widely used in construction. 

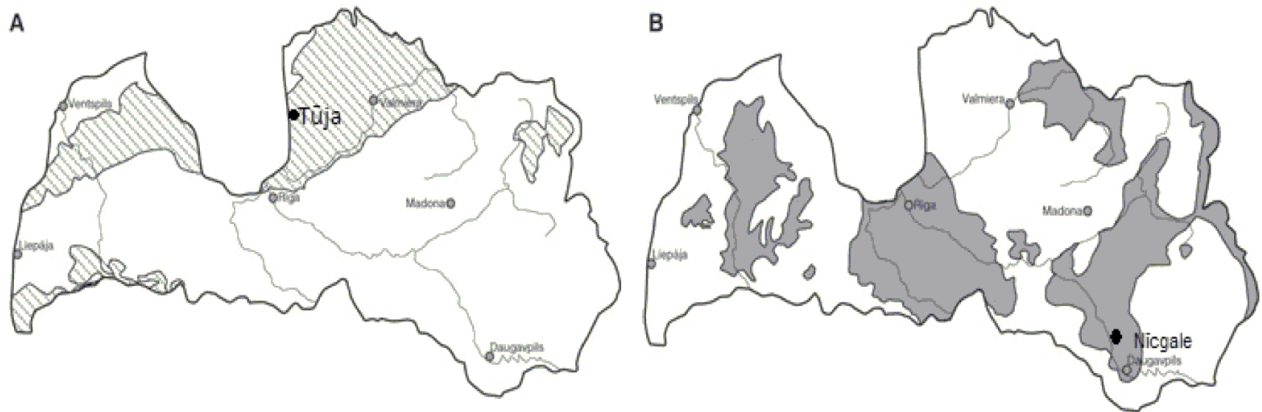

Fig.3. Latvian clay deposits (A - Devonian period; B - Quaternary period).

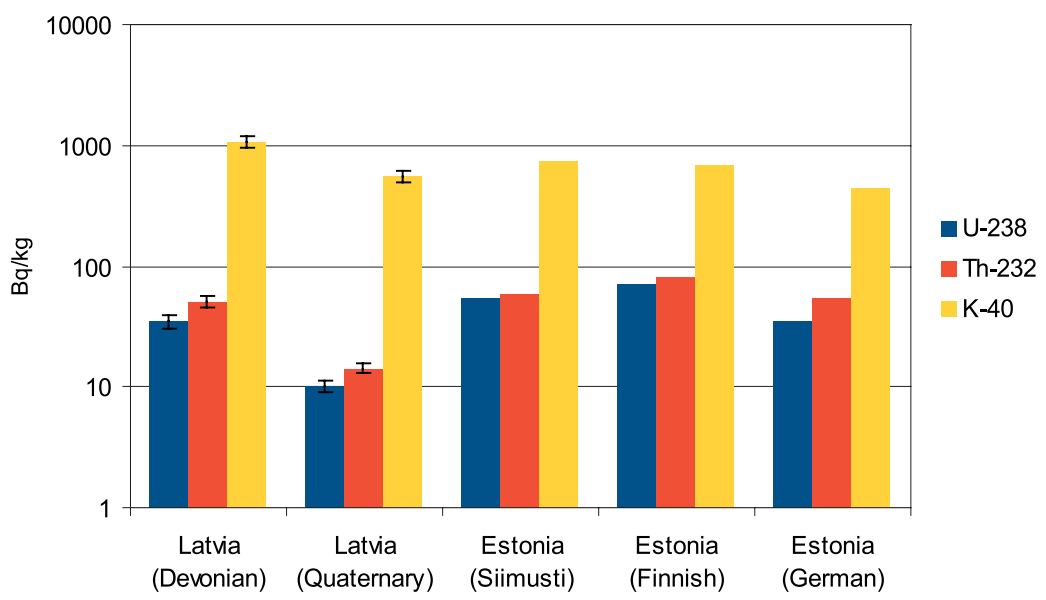

Fig.4. Average concentrations of radionuclides in different clays used in Latvia and Estonia (Estonian data taken from [8]).

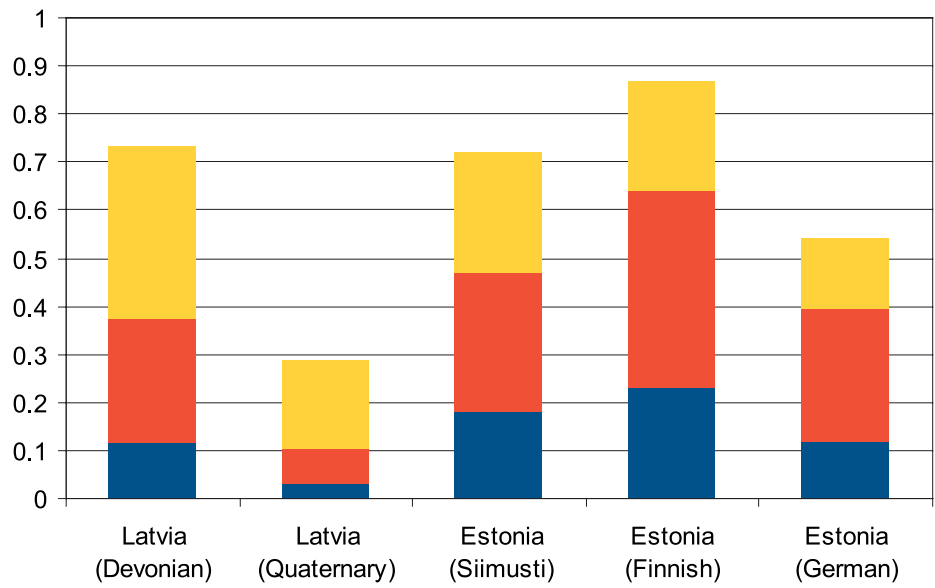

Fig.5. Average activity index values of measured clay samples. 


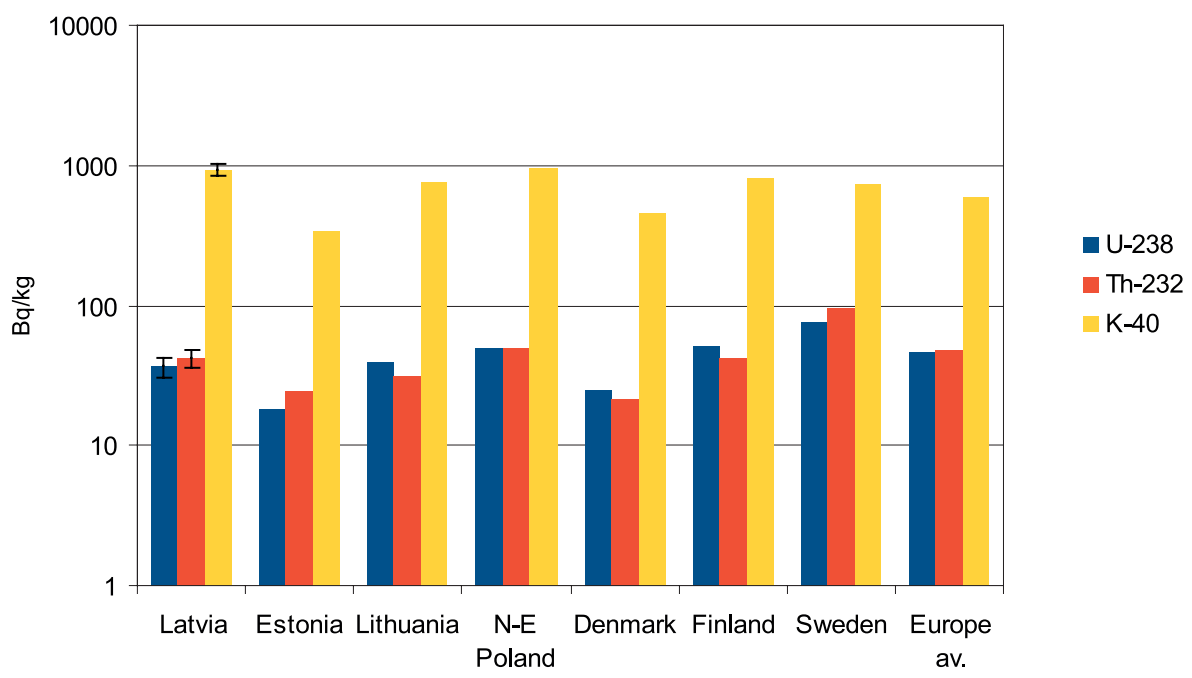

Fig.6. Average concentrations of radionuclides in clay bricks used in Latvia and their comparison with the data from other Baltic region countries [1,8-10].

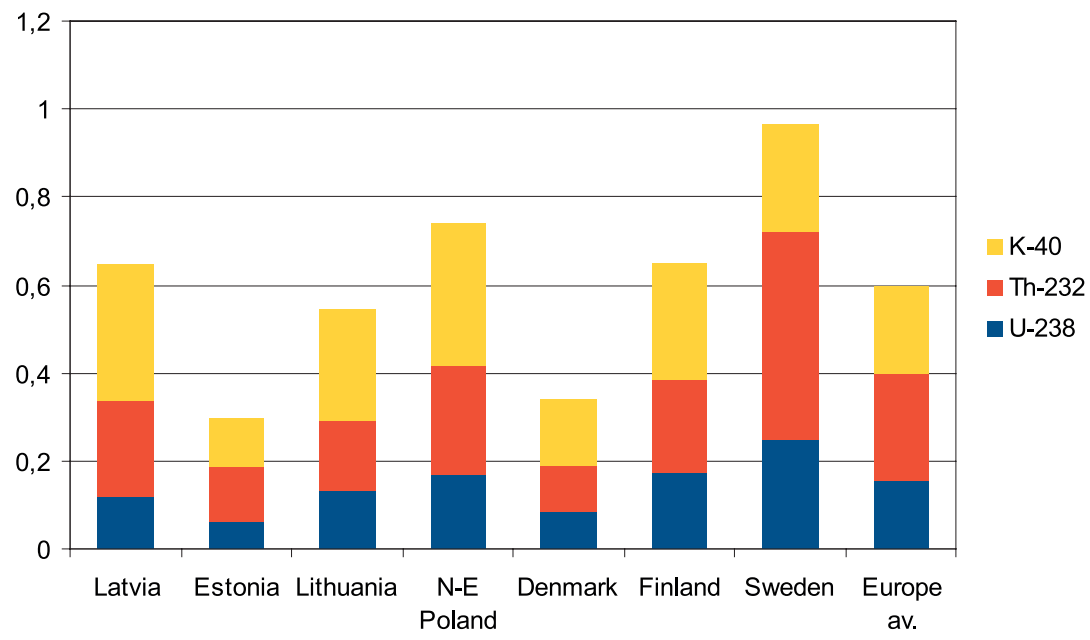

Fig. 7. Average activity index values of clay bricks.

Table 2 presents a comparison of NORM activity values obtained for Latvian Devonian, and Quaternary period clays with corresponding world average values for soil [1]. One can see that Latvian soil contains comparably high concentration of $\mathrm{K}-40$ exceeding world average values.

Clays from the Devonian period deposit (Tuja, Salacgrivas district, Latvia), in comparison with those of the Quaternary period (Nicgale), have almost two times higher K-40 activity, and about 3.5 times higher activity of Th-232 and U-238 decay chain products. Notably higher Th-232 and U-238 decay product activity was also observed in the imported firebricks. 
Average Natural Radionuclide Concentration in Clay, Bq/kg

\begin{tabular}{cccc}
\hline Nuclide & $\begin{array}{c}\text { Latvia } \\
\text { (Devonian clay) }\end{array}$ & $\begin{array}{c}\text { Latvia } \\
\text { (Quaternary clay) }\end{array}$ & $\begin{array}{c}\text { World } \\
\text { (soil average) }\end{array}$ \\
\hline K-40 & $1078(108)$ & $553(52)$ & 400 \\
Th-232 & $51.6(6)$ & $14.2(13)$ & 30 \\
U-238 or Ra-226 & $34.8(4)$ & $10(11)$ & 35 \\
\hline
\end{tabular}

The evaluated activity index I value for the clay samples taken from Tuja is 0.73 , for the measured samples of clay bricks produced in Latvia -0.65 , while for the firebricks I=11.6, which considerably exceeds the permitted activity limit. According to the EU recommendations [3], two groups of buildings are provisioned with regard to received annual external gamma radiation dose: a) $\leq 0.3 \mathrm{mSv}$; b) $\leq 1 \mathrm{mSv}$. For the first group of buildings, materials can be used in bulk amounts only when their activity index $\mathrm{I} \leq 0.5$, while for the second group, when $\mathrm{I} \leq 1$. Therefore, clay bricks produced in Latvia are not suitable for construction of buildings with higher radiation safety standards. But the imported firebricks cannot be used for construction even on the restricted basis allowing $\mathrm{I} \leq 6$ for the second group of buildings.

Natural radionuclide contents in clay bricks have also been compared (see Figs. 6 and 7) with the available data [1, 6-10] from different North European and Baltic countries as well as with the European average values [7]. One can see that the average activity index value for the Devonian clay in Latvia is approximately the same as for the local origin clay in Estonia (Siimusti) [8]. Estonian clay has higher activity of Th-232 and U-238 decay products, characteristic of such North European countries as Finland and Sweden. Latvian clay and local production clay bricks have higher activity of K-40, slightly above that of Lithuanian bricks [7], [9]. It is worth noting that, while the natural radionuclide level in Latvian and Estonian clay is similar, the activity index for bricks differs by almost two times. A possible explanation can be that the bricks measured in [8] were either imported or produced from the imported clay.

\section{CONCLUSIONS}

The obtained results have been compared with the national and EU radiation safety requirements. It has been found that:

1. Activity index for all tested building materials, except the imported granite and firebricks, is below radionuclide concentration level permissible in Latvia [5]. Hence, the use of these materials for construction is safe for the inhabitants.

2. Average concentrations of natural radionuclides and activity index values for clay and clay bricks used in Latvia are on the same level as in other Baltic and North European countries, except Sweden. 
3. However, radionuclide content in different period clay deposits of Latvia can differ by more than two times, and up to five times in different clay products. Therefore, clay products should be subjected to more stringent control.

\section{REFERENCES}

1. UNSCEAR. (2000). Sources and Effects of Ionizing Radiation. Report to General Assembly, Vol.1, Annex B. New York: United Nations.

2. NEA-OECD. (1979). Nuclear Energy Agency. Exposure to radiation from natural radioactivity in building materials. Report by NEA Group Experts. Paris: OECD.

3. European Commission. (1999). Radiological Protection Principles Concerning the Natural Radioactivity of Building Materials. Radiation Protection 112. Luxembourg: EC.

4. European Commission. (1996). Council Directive 96/29/EURATOM. Luxembourg: EC.

5. Latvian Cabinet of Ministers. (2002). Regulation of Protection against Ionising Radiation. Regulations No.149, adopted 09.04.2002. Riga.

6. Nuccetelli, C., Risica, S., D’Alessandro, M., Trevisi, R. (2012). Natural radioactivity in building materials in the European Union: Robustness of the activity concentration index I and comparison with a room model. Journal of Radiological Protection 32, 349-358.

7. Trevisi, R., Risica, S., D’Alessandro, M., Paradiso, D., Nuccetelli, C. (2012). Natural radioactivity in building materials in the European Union: a database, and an estimate of radiological significance. Journal of Environmental Radioactivity 105, 11-20.

8. Lust, M., Realo, E. (2012). Assessment of natural radiation exposure from building materials in Estonia. Proceedings of the Estonian Academy of Sciences 61(2), 107-112.

9. Peciuliene, M., Jasaitis, D., Girgzdys, A. (2006). Natural radionuclides in the soil of the Vilnius city and assessment of their hazard. Geologia 55, 9-14.

10. Zalewski, M., Tomczak, M., Kapata, J. (2001). Radioactivity of Building Materials Available in Northeastern Poland. Polish Journal of Environmental Studies 10(3), 183-188.

11. Latvian State Standard. (2000). LVS/ISO 257:2000. Building material quality - Determination of radionuclides and specific activity of radionuclides in building materials by gamma-ray spectrometry. Riga.

12. International Organization for Standardization. (2005). ISO 18589-1:2005 Measurement of radioactivity in the environment - Soil - Part 1: General guidelines and definitions.

13. International Organization for Standardization. (2005). ISO 18589-1:2007 Measurement of radioactivity in the environment - Soil - Part 2: Guidance for the selection of the sampling strategy, sampling and pre-treatment of samples.

14. International Organization for Standardization. (2005). ISO 18589-1:2007 Measurement of radioactivity in the environment - Soil - Part 3 Measurement of gamma-emitting radionuclides.

15. Canberra industries. (1997). GENIE-2000, Basic Spectroscopy (Standalone) VI.2A Copyright (c).

16. Dan Gabriel Cacuci (Ed). (2010). Handbook of Nuclear Engineering. Vol.1. Nuclear Engineering Fundamentals. Springer.

17. International Organization for Standardization. (2008). ISO/IEC 17025:2005 General requirements for the competence of testing and calibration laboratories.

18. Dabare, L., Svinka, R., Svinka, V. (2012). Sorption of inorganic substances on the porous Latvian clay ceramic. Latvian Journal of Chemistry 4, 383-389. 


\title{
DABĪGĀ RADIOAKTIVITĀTE MĀLOS UN LATVIJĀ PIELIETOTOS BŪVMATERIĀLOS
}

\author{
D. Riekstiṇa, J. Bērziņš, T. Krasta, R. Švinka, O. Skripnika
}

\section{Kopsavilkums}

Darbs prezentē dabīgo radionuklīdu koncentrācijas un aktivitātes indeksa pētijjumus Latvijā izmantotajos būvmateriālos. Īpaša uzmanība pievērsta mālam un māla keramikai. Lai noteiktu K-40 un Th-232, U-238 radioaktivitāti, pielietota gamma-spektrometrijas metode. Atsevišķos izstrādājumos konstatētās maksimālās koncentrācijas bija: K-40 - 1440 Bq/kg, U-238 - 175 Bq/kg. Granìtam noteiktā maksimālā Th-232 koncentrācija bija $210 \mathrm{~Bq} / \mathrm{kg}$. Konstatēts, ka Devona perioda māla depozîtos radionuklīdu koncentrācija ir vairāk nekā divas reizes lielāka nekā Kvartāra perioda māla depozītos, bet dažādos māla keramikas izstrādājumos koncentrācijas var atšķirties pat piecas reizes. Iegūtie rezultāti tiek salīdzināti ar analogiskiem datiem no citām Baltijas un Ziemel̦eiropas valstīm.

01.04.2015. 